\title{
Inventory Changes With Information Asymmetry And Informed Trading Patterns In The Korean Stock Market
}

\author{
Gyungmin Pyo, Konyang University, Chungnam, South Korea
}

Yerim Chung, Yonsei University, South Korea

\begin{abstract}
In this paper, we examine how inventory changes are related to the trading patterns of foreign and institutional investors, especially in firms with information asymmetry. Prior researchers report that inventory changes could be associated with firm performance, earnings management, stock returns, and incentive contracts. In this study, we focus on the relationship between trading patterns of informed traders and changes in inventory, testing how inventory changes are associated with the investment decision-making of informed traders. After controlling for firm-specific factors, we find a significant relationship between changes in inventory and trading patterns of institutional and foreign investors. Under conditions of high information asymmetry, the negative relation between institutional trading and inventory changes is enhanced. However, the amounts invested by foreign traders are negatively associated with increases in inventory even in firms with low information asymmetry. We infer that foreign traders exhibit more conservative trading patterns than institutional investors.
\end{abstract}

Keywords: Information Asymmetry; Informed Trading Patterns; Inventory

\section{INTRODUCTION}

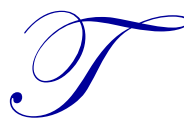

he informativeness of financial reports is an important issue in accounting. To improve comparability and informativeness of financial reports on a global scale, Korea adopted the IFRS (International Financial Reporting Standards) in 2011. Inventory is an important item included in most financial reports. After the introduction of the Just in Time system, many firms chose to focus on inventory changes as part of their operations strategy. Information about inventory generally includes data regarding cost efficiency, earnings management, operations strategy, incentive contracts, and many other business strategies. Moreover, research on lean manufacturing has emphasized the reduction of inventory levels (e.g., Baiman et al., 2010). In this study, we focus on trading patterns of informed traders who have more precise information about inventory levels, and we test how inventory changes are associated with investment by informed traders according to the level of information asymmetry.

Early research on inventory (e.g., Baiman et al., 2010; Sun, 2010; Thomas and Zhang, 2002) emphasizes the effect of inventory changes on accruals, future stock returns, incentives in the form of compensation, profitability, and sales growth in firms. Baiman et al. (2010) provide analytic models of the relation between inventory buffers and performance metrics in incentive contracts for agents. According to Sun (2010), inventory changes in MD\&A disclosures are associated with return on assets and sales growth in future periods. Thomas and Zhang (2002) also find that inventory changes affect the negative relation between accruals and future stock returns. Therefore, since the inventory level has been a critical factor for predicting future performance and interpreting current status of firms, we examine the effect of inventory changes on trading decision-making by informed traders.

Informed traders are generally distinguished between inside traders and outside informed traders. In this study, we define informed traders as outsiders such as institutional traders and foreign traders. Since informed 
traders of these two types play major roles in the Korean stock market and the information about each trading is provided on daily basis, an investigation of the trading patterns of institutional and foreign investors is an appropriate way to test the impact of inventory changes on informed trading (Choe et al., 2005). Compared to domestic institutional traders, foreign traders based on their expertise may be able to realize more returns (Grinblatt and Keloharju, 2000). However, foreign traders have limited access to local information about firm performance and tend to be less informed than domestic informed traders (Brennan and Cao, 1997). If foreign traders are less informed than domestic traders, they may prefer to avoid investment risk and behave more conservatively than their more sophisticated, better-informed domestic counterparts. Thus, we predict that if foreign traders have advantages in terms of trading over domestic informed traders, foreign traders may reflect the information of inventory changes and timely respond to the level of inventory. On the other hand, if foreign traders have a disadvantage compared to domestic traders because of information asymmetry, foreign traders may reflect the lagged information of inventory changes and react conservatively to time-lag inventory changes in order to avoid investment risk.

To test the association between inventory changes and the trading activities of informed investors, we examine changes in the amount of informed trading. We also analyze information asymmetry in each firm through the ratio of bid-ask spreads, which is utilized as a proxy for investment risk in stock trading. When firms experience high levels of information asymmetry, the effect of inventory changes on informed traders' decision-making tends to be enhanced because informed traders are better able to evaluate investment risk in each company and reflect this information in their investment decisions. In such cases, we can infer that information asymmetry may have informativeness for informed investors in interpreting the meaning of inventory changes made by firms.

After controlling for firm-specific factors, we find that inventory changes are associated with changes in the amount of foreign and institutional trading. Furthermore, we demonstrate that the negative relation between institutional trading and the change in inventory is enhanced when firms experience high level of information asymmetry. Institutional traders are likely to reflect timely information about the current changes in inventory and reduce buying and selling when firms with information asymmetry increase their current inventory. When we consider the abnormal inventory in our model, we find that institutional traders also reduce buying when abnormal inventory increases in firms with information asymmetry. However, although trading of foreign traders is associated with increase in current inventory, the effect of information asymmetry is insignificant. In the model including abnormal inventory, a negative relationship is observed between amounts invested by foreign investors and previous abnormal inventory, and the effect of information asymmetry is also insignificant. From these results, stakeholders in the capital market can learn about the influence of changes in inventory in firms with information asymmetry on informed trading patterns. Also, these results indicate that inventory changes can be informative for informed traders, who tend to respond to current or previous changes in inventory and reflect this information in their decision-making according to the level of information asymmetry in each firm. We also find that the decisions of informed traders reflect abnormalities in inventory during current or previous periods. Taken together, we infer from the results that inventory changes have informativeness in the capital market, but that foreign traders show more conservative trading patterns than institutional traders because the former unconditionally reduce trading amounts in accordance with current or previous inventory increases even in firms with low levels of information asymmetry.

This study adds to the existing literature on the relationship between informed trading and inventory changes by providing additional evidence of this relationship in firms with information asymmetry. Unlike previous studies, we focus on informed trading patterns, demonstrating a significant association between inventory increases and informed trading. We find that sophisticated traders are eager to respond to informative items in financial reports regarding their investment decisions. Further, we show that foreign traders tend to behave in a more conservative manner than domestic informed investors. Also, we provide evidence that domestic traders respond to inventory changes according to the level of information asymmetry in a given firm. From this study, capital market participants may also improve their understanding of the informativeness of current inventory with regard to investment risk.

The rest of this paper is organized into five sections. The second section provides the study background and develops the hypotheses. The third section discusses the research method and data selection procedures. The fourth section presents our empirical results, and the last section concludes the study. 


\section{BACKGROUND AND HYPOTHESES}

\section{Inventory}

The traditional view of inventory is that raw materials, work in process, and finished goods of resalable or realizable value are categorized as inventory for the purposes of reporting the financial status of firms. Prior studies on inventory (Jiambalvo, 1997; Roychowdhury, 2006; Sun, 2010; Thomas and Zhang, 2002) emphasize the effect of inventory changes on abnormal stock returns, accruals, earnings management, profitability, and sales growth in firms. Jiambalvo (1997) suggests the following variable for measuring inventory changes: the change in the percent of production added to inventory (CPAI), examining the effect of overproduction on abnormal stock returns. By allocating some of their current fixed manufacturing overhead costs to inventory, managers are able to manipulate net income caused by excess production. In this case, firms can record earnings surprise in their financial reports only for the current period. The long-term effects of increases in CPAI on stock prices are insignificant (Jiambalvo, 1997). Roychowdhury (2006) also suggests another type of inventory: abnormal inventory. Observing production costs with abnormal inventory and abnormal COGS (cost of goods sold), we see that managers who want to manipulate earnings tend to reduce production costs by stimulating overproduction. However, this phenomenon is less prevalent when investors are well informed. Sun (2010) shows a positive association between favorable explanations for inventory changes in MD\&A disclosure and return on assets and sales growth in future periods. Thomas and Zhang (2002) also find an effect of inventory changes on the negative relation between accruals and future stock returns. Therefore, since inventory is clearly critical for predicting future performance and interpreting current financial status, we examine the effect of inventory changes on trading decisions made by informed traders.

Baiman et al. (2010) provide an analytic model of the relation between the inventory buffer and the performance metric in incentive contracts for agents. If an agent is compensated based on realized throughput (e.g., output per unit of time), the inventory buffer is affected by that agent's incentive and optimal compensation. The results of that study suggest that decreases in inventory buffer are efficient only when reducing the inventory buffer intensifies the informativeness of the performance scheme. Many studies in economics, accounting, and operations management focus on inventory changes because the effects of these changes are associated with current and future earnings, stock prices, managers' opportunistic behaviors, and compensation structures. Unlike in prior studies, in this study we investigate informed trading patterns and inventory changes in firms with information asymmetry. Informed traders are able to evaluate inventory changes differentially, collect more precise information, and respond more sensitively to changes in the level of information asymmetry in each firm than uninformed outsiders. Thus, we test trading patterns of informed traders and changes in investment decision-making as related to inventory changes in firms with information asymmetry.

\section{Information Asymmetry}

Easley and O'Hara (2004) report that information asymmetry is related to the cost of capital. In addition, information asymmetry affects firm value. Copeland and Galai (1983) suggest an analytic model in which a positive effect of bid-ask spreads on market price and return variance is implied. Since high bid-ask spreads are associated with high information asymmetry (Chae, 2005), we utilize bid-ask spreads to test the relation between inventory changes and informed trading under conditions of information asymmetry. According to our prediction, informed traders tend to recognize the level of information asymmetry and reduce trading amounts correspondingly in order to avoid investment risk.

When inventory changes are due to the increase of customer orders, informed traders will increase trading. On the other hand, inventory changes may imply bad news about firms, indicating earnings management or opportunistic behavior on the part of managers. In such cases, informed traders may reduce trading in firms with increased inventory. Also, the characteristics of informed traders may vary. Some may be at a disadvantage in utilizing information about inventory and may therefore behave more conservatively than other informed traders. To test the relation between informed trading and inventory changes, we present our first hypothesis, as follows:

H1: Changes in inventory are associated with buying and selling patterns of foreign or institutional traders. 
Informed traders are regarded as sophisticated investors who can collect precise and useful information in order to record high returns. If informed traders recognize the level of investment asymmetry in firms, then they may only decrease trading amounts in firms with increased inventory and high investment risk. This argument leads to our second hypothesis.

H2: Changes in inventory in firms with information asymmetry are associated with reduced buying and selling patterns of foreign or institutional traders.

In addition, when we utilize abnormal inventory changes, we can rule out trends in inventory changes due to variations in customer ordering and the effects of management strategy, operations strategies of peer companies, or global economic issues. Including abnormal inventory, we present the third and fourth hypotheses:

H3: Abnormal inventory is associated with buying and selling patterns of foreign or institutional traders.

H4: Abnormal inventory in firms with information asymmetry are associated with reduced buying and selling patterns of foreign or institutional traders.

If the results show a significant relation between inventory changes and trading patterns of foreign and institutional traders, we can show the incremental effects of information asymmetry on inventory changes and informed trading patterns.

\section{RESEARCH METHODS AND DATA SELECTION}

To determine how inventory changes are associated with the trading patterns of informed traders, we employ variables representing inventory changes, the amount of institutional and foreign trading, an indicator for information asymmetry, and interaction terms among inventory changes and information asymmetry. To measure inventory changes, we utilize the measure developed by Jiambolvo et al. (1997) and Roychowdhury (2006). For the level of information asymmetry, we use the ratio of bid-ask spreads, which can be considered a proxy for information asymmetry and investment risk (Chae, 2005; Copeland and Galai, 1983).

\section{The Change In The Percent Of Production Added To Inventory}

Jiambalvo et al. (1997) suggest that the change in the percent of production added to inventory (CPAI) is appropriate as an indicator for overproduction in firms. Since $C P A I$ reflects the change in the ratio between producing and selling amounts, increases in $C P A I$ only related to reducing production costs through overproduction are easily captured by the ratio. When we utilize $C P A I$ in our test model, the effects of overproduction on inventory for earnings manipulation are readily compared. CPAI is computed in equation (1) according to the method of Jiambalvo et al. (1997).

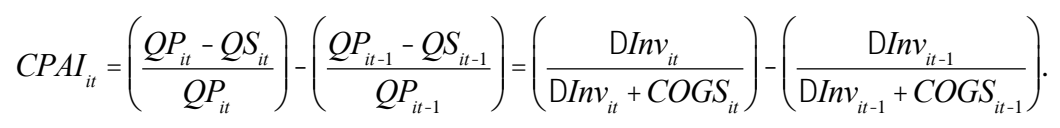

where

$C P A I=$ the change in the percent of production added to inventory in year $\mathrm{t}$ for firm $\mathrm{i}$;

$Q P=$ the quantity produced in year $\mathrm{t}$ for firm $\mathrm{i}$;

$Q S=$ the quantity sold in year $\mathrm{t}$ for firm i;

$\Delta I n v=$ the difference between inventory in year $\mathrm{t}$ and in year $\mathrm{t}-1$ for firm $\mathrm{i}$; and

$C O G S=$ the cost of goods sold in year $\mathrm{t}$ for firm $\mathrm{i}$. 


\section{Abnormal Inventory}

The CPAI measure has the advantage of matching the effect of overproduction. However, trends in inventory may change due to variations in customer ordering and the effects of operations strategies or global economic issues. These factors are rarely controlled in models including CPAI. Therefore, in order to control for these factors, we employ another method involving abnormal inventory. We utilize the normal inventory growth model as suggested in Roychowdhury (2006). In this model, firms with high residual value correspond to firms with high abnormal inventory. Since residuals are calculated using estimation errors, we compute each firm's residuals within each industry in year clusters. Residuals for abnormal inventory are calculated using equation (2), as in Roychowdhury (2006).

$$
\frac{\operatorname{In} v_{i t}}{A_{i t 1}}={ }_{0}+{ }_{1} \frac{1}{A_{i t}}+2 \frac{S_{i t}}{A_{i t}}+{ }_{3} \frac{S_{i t 1}}{A_{i t 1}}+{ }_{i t} \text {. }
$$

where

$\Delta I n v=$ the difference between inventory in year $\mathrm{t}$ and in year $\mathrm{t}-1$ for firm $\mathrm{i}$;

$A=$ the total assets in year $\mathrm{t}-1$ for firm i;

$\Delta S=$ the difference between sales in year $\mathrm{t}$ and year $\mathrm{t}-1$ for firm $\mathrm{i}$; and

Abnormal inventory $=$ the estimated residuals from model (2).

\section{Spreads}

We categorize firms with high levels of information asymmetry as follows. Firms with top quartile ranked spreads correspond to firms with high information asymmetry. Since spreads are based on daily trading data, we sum up the difference between the daily bid and the ask price. Yearly stock spreads are computed as in equation (3). The mean of daily spreads is utilized for the yearly spread ratio.

$$
\operatorname{SPREAD}_{i t q}=\frac{1}{N} \quad{ }_{d=1}^{N}\left(a_{i s k_{i t d}} \quad \text { bid }_{i t q d}\right)
$$

where

$S P R E A D=$ the difference between the daily bid and ask price on day $\mathrm{t}$ for firm $\mathrm{i}$;

ask $=$ the daily ask price for firm $\mathrm{i}$; and

$b i d=$ the daily bid price for firm $\mathrm{i}$.

\section{Research Model}

As in prior studies (e.g., Jiambalvo, 1997; Roychowdhury, 2006; Sun, 2010; Thomas and Zhang, 2002), in this study we expect that inventory changes and information asymmetry influence firm performance and the trading patterns of informed traders. The following model, equations (4) and (5), is used to test the four hypotheses:

$$
\begin{aligned}
& \text { Inst_Absv } v_{i t} \quad={ }_{0}+{ }_{1} I A_{i t}+{ }_{2} p C P A I_{i t}+{ }_{3} p C P A I * I A_{i t}+{ }_{4} C P A I_{i t}+{ }_{5} C P A I * I A_{i t} \\
& (\text { or Netv, Buyv,Sellv })_{i t}+{ }_{6} S_{Z} I E_{i t}+{ }_{7} B M_{i t}+{ }_{8} R E T_{i t}+{ }_{9} S T D_{i t}+{ }_{10} F_{0} r_{-} B u y v_{i t} \\
& +\quad \text { IND\&YEAR }{ }_{i t} \text {. } \\
& \text { For_Absv } v_{i t} \quad={ }_{0}+{ }_{1} I A_{i t}+{ }_{2} p C P A I_{i t}+{ }_{3} p C P A I * I A_{i t}+{ }_{4} C P A I_{i t}+{ }_{5} C P A I * I A_{i t} \\
& (\text { or Netv, Buyv, Sellv })_{i t}+{ }_{6} S_{Z} E_{i t}+{ }_{7} B M_{i t}+{ }_{8} R E T_{i t}+{ }_{9} S T D_{i t}+{ }_{10} I_{n s t} B_{B u y v} \\
& +\quad I N D \& Y E A R+{ }_{i t} \text {. }
\end{aligned}
$$


where

definitions of variables provided in Table 8.

As in prior studies (Cohen et al., 2012; Smith and Watts, 1992; Choe et al., 2005; Watanabe, 2008), in this study we expect that firms with lower book to market values, higher returns, and greater volatility are likely to have more information asymmetry and stronger reactions from informed traders.

Based on prior research, several control variables are added. SIZE may reflect the effects of omitted variables on the investment environment (Cohen et al., 2012). BM is also important, implying that if firms have growth options and a low BM, then investors cannot avoid information asymmetry (Smith and Watts, 1992). We also add RET and STD because stock returns and stock volatility tend to influence informed trading volumes (Watanabe, 2008). To measure STD, yearly stock volatility is computed based on the mean difference between daily low and high prices scaled by the mean stock price. In addition, heterogeneous informed traders are affected by other informed trading, and foreign traders sometimes respond to the behaviors of domestic investors (Choe, 2005). Therefore, in order to control for heterogeneity in the relative effects among informed traders, we employ For_Buyv in model (4) and Inst_Buyv in model (5). In this study, we compute each firm's ratio from each industry in year clusters in order to adjust for industrial and periodic effects.

Table 1: Sample Descriptions

\begin{tabular}{lr}
\hline Panel A. Sample Selection Criteria 2008-2010 & Observations \\
\hline All firm-year observations from the Korea Stock Exchange (KSE) & 2,340 \\
(Less) Financial service & $(258)$ \\
(Less) Firm-year observations with insufficient financial data & $(329)$ \\
(Less) Firm-year observations with insufficient trading data & $(41)$ \\
(Less) Firm-year observations with negative equity & $(3)$ \\
Final Sample Size & $\underline{1,709}$ \\
\hline
\end{tabular}

Panel B. Sample by Year

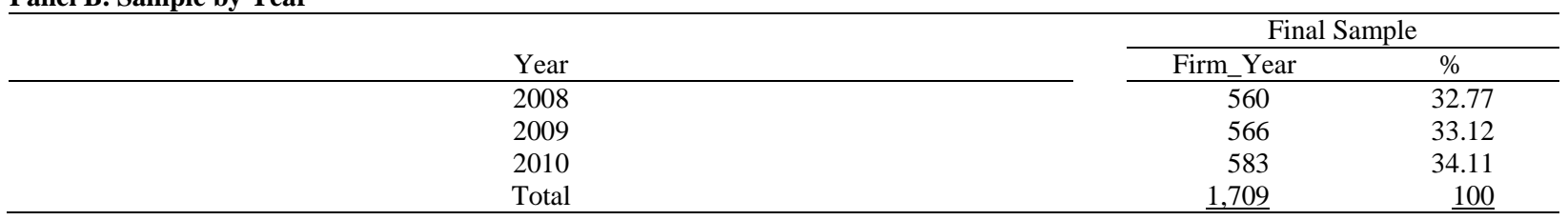

Panel C. Sample by Industry

\begin{tabular}{|c|c|c|}
\hline \multirow[b]{2}{*}{ Industry } & \multicolumn{2}{|c|}{ Final Sample } \\
\hline & Firm_Year & $\%$ \\
\hline Electronic Components and Precision Instruments & 166 & 9.71 \\
\hline Cokes, Medicinal, Non-metallic, Metal, and Chemical Products & 554 & 32.42 \\
\hline Motor Vehicles and Transportation Products & 118 & 6.90 \\
\hline Other Manufacturing & 347 & 20.30 \\
\hline Construction Activities & 90 & 5.27 \\
\hline Information and Communication Service Activities & 54 & 3.16 \\
\hline Retail, Wholesale, Other service, and Other activities & 380 & 22.24 \\
\hline Total & $\underline{1,709}$ & $\underline{100}$ \\
\hline
\end{tabular}

\section{Data Selection}

Table 1 presents the sample used in this study. Because the global financial crisis started in 2007, leading to a global recession from 2008-2012, and mandatory adoption of the IFRS (International Financial Reporting Standards) has been in effect in Korea from 2011, the test period in this study extends from 2008 to 2010. We exclude firm-year observations in financial service industries, firms with insufficient financial and trading data, and those with negative equity. Panels B and $\mathrm{C}$ of Table 1 provide distributions in each year and industry, indicating that 
clusters by year and industry are not a serious concern. Financial data were extracted from the KIS-VALUE ${ }^{1}$ database by the NICE Information Service, and trading data were extracted from the Fn-guide database ${ }^{2}$ by FnGuide, Inc. Bid and ask spreads were extracted from the Bloomberg database. Korean trading data may be useful to compare the behavior of sophisticated domestic investors (institutional traders) with that of foreign traders because foreign traders must register with the Financial Supervisory Service (FSS) and use their ID number for trading stocks (Choe et al., 2005).

\section{EMPIRICAL RESULTS}

\section{Descriptive Statistics}

Table 2 shows descriptive statistics for the dependent, independent, and control variables. In this study, we use winsorized values for continuous variables at the 1st and the 99th percentiles in order to control the effects of extreme observations. The mean value of the total trading ratio by institutional investors (Inst_Absv) is 0.0512 , and the absolute trading value is the change in the sum of buying and selling amounts in between the test period and the previous year, scaled by market value. ${ }^{3}$ The mean value of the net trading ratio (Inst_Netv, -0.0113 ) is similar to the net trading amounts by buying less than selling amounts of institutional traders (Inst_Buyv, 0.0300 and Inst_Sellv, 0.0414). For_Absv has a mean value of 0.0397 , and the mean value of For_Netv is 0.0129 , which is the net amount of stock buying and selling by foreign investors (For_Buyv, 0.0294 and For_Sellv, 0.0188). While the average value of For_Netv is positive, the average value of Inst_Netv is negative. This indicates that foreign traders may deposit more money in Korean stocks than domestic institutional traders in this test sample. The binary variable for the firms with high levels of information asymmetry $(I A)$ is 0.2411 , which refers to top-quartile ranked firms in our sample. Regarding the level of information asymmetry, firms with high levels of quoted stock spreads ratio over the top quartile have a value of 1 , and a value of 0 is allocated to other firms in our final sample.

Table 2: Descriptive Statistics

\begin{tabular}{|c|c|c|c|c|c|c|c|}
\hline $\begin{array}{l}\text { Variables } \\
(\mathrm{N}=1,709)\end{array}$ & MEAN & STD & Min & Q1 & Median & Q3 & Max \\
\hline Inst_Absv & 0.0512 & 0.4090 & -0.9853 & -0.0987 & $\overline{0.0000}$ & 0.0938 & 1.5545 \\
\hline Inst_Netv & -0.0113 & 0.1935 & -0.7303 & -0.0700 & -0.0001 & 0.0417 & 0.6164 \\
\hline Inst_Buyv & 0.0300 & 0.2634 & -0.6343 & -0.0597 & 0.0000 & 0.0390 & 1.1359 \\
\hline Inst_Sellv & 0.0414 & 0.2638 & -0.5931 & -0.0422 & 0.0000 & 0.0640 & 1.1268 \\
\hline For_Absv & 0.0397 & 0.3580 & -0.8569 & -0.1129 & 0.0000 & 0.1394 & 1.2799 \\
\hline For_Netv & 0.0129 & 0.1387 & -0.4768 & -0.0226 & 0.0009 & 0.0471 & 0.5106 \\
\hline For_buyv & 0.0294 & 0.2137 & -0.5047 & -0.0515 & 0.0000 & 0.0768 & 0.8327 \\
\hline For_Sellv & 0.0188 & 0.2244 & -0.5920 & -0.0620 & 0.0000 & 0.0707 & 0.8297 \\
\hline$I A$ & 0.2411 & 0.4279 & 0 & 0 & 0 & 0 & 1 \\
\hline$p C P A I$ & 0.0090 & 0.1073 & -0.1463 & -0.0034 & -0.0002 & 0.0007 & 0.9607 \\
\hline CPAI & -0.0012 & 0.1871 & -1.0000 & -0.0295 & 0.0004 & 0.0288 & 1.0023 \\
\hline pAbn_Inv & -0.0009 & 0.9613 & -2.5758 & -0.4842 & -0.0528 & 0.4241 & 2.9594 \\
\hline Abn_Inv & -0.0010 & 0.9674 & -2.6699 & -0.4905 & -0.0390 & 0.3988 & 3.0887 \\
\hline$S I Z \bar{E}$ & 26.5017 & 1.4733 & 23.9915 & 25.4346 & 26.1973 & 27.3109 & 30.7195 \\
\hline$B M$ & 1.5232 & 1.0570 & 0.1465 & 0.7459 & 1.2764 & 1.9971 & 5.5665 \\
\hline RET & 0.0061 & 0.0258 & -0.0518 & -0.0109 & 0.0056 & 0.0225 & 0.0730 \\
\hline STD & -0.0090 & 0.0396 & -0.1107 & -0.0346 & -0.0080 & 0.0164 & 0.0905 \\
\hline
\end{tabular}

\footnotetext{
${ }^{1}$ The KIS-VALUE database in Korea provides both financial and stock market data for firms listed on the Korea Stock Exchange and KOSDAQ markets, which are equivalent to COMPUSTAT and CRSP in the U.S.

${ }^{2}$ The FnGuide database includes informed trading information, and is equivalent to the I/B/E/S.

${ }^{3}$ To avoid endogeneity issues, we compute all dependent variables, Inst_Absv, Inst_Netv, Inst_Buyv, Inst_Sellv, For_Absv, For_Netv, For_Buyv, and For_Sellv, using the difference in trading amounts scaled by market value between the test year and the previous year.
} 
Table 3 presents the correlation matrix of the variables used in the empirical analyses. The highest correlation of continuous dependent variables is about 0.55 , which is between For_Buyv and $R E T^{4}$ in the analysis model (3). The remaining variables are not highly correlated. The highest VIF value in the regression analyses is below 0.97 and the condition index (not tabulated) is low, indicating that multicollinearity is not a serious concern. ${ }^{5}$

Table 3: Pearson Correlation Matrix

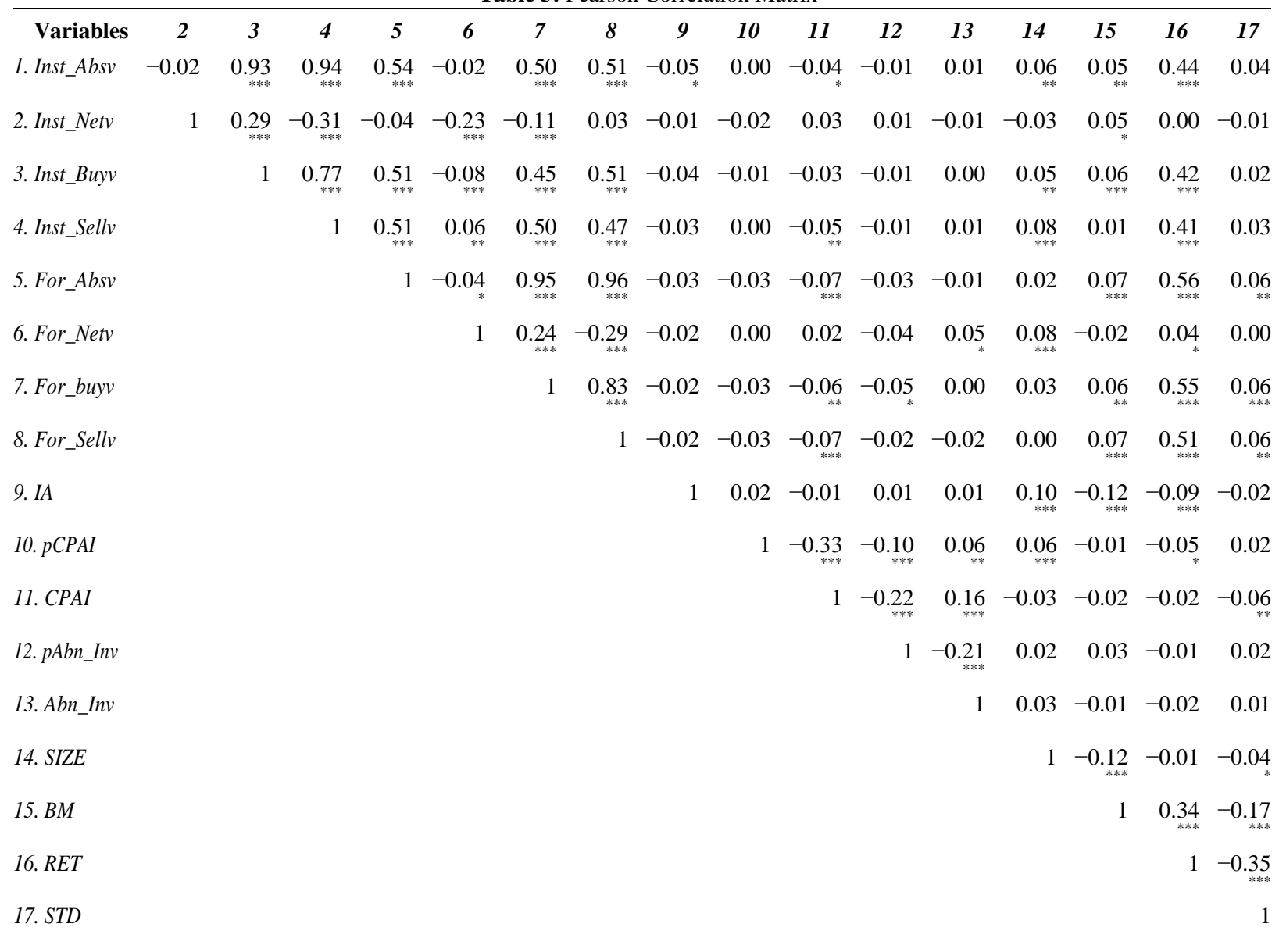

\section{Regression Results: the Change in the Percent of Production added to Inventory}

Table 4 provides the empirical results of multivariate regressions for testing two of the hypotheses. The Inst_Absv model shows the relation between the change in inventory (CPAI) and absolute total trading amounts of institutional investors. $C P A I^{*} I A$ is significant and negatively associated with Inst_Absv at a significance level of 1 percent. When firms have high levels of information asymmetry based on bid-ask spreads, institutional investors are likely to avoid risk and reduce stock trading amounts for firms with increases in inventory. Since total assets in many firms will be increased due to the increased inventory, informed traders may respond positively to their expanded assets. Generally, when firms prepare for growing customer orders, they expand their inventory in terms of work in process, materials, or finished goods. However, some firms may hold the goods or materials opportunistically in order to reduce the cost of goods sold during some fiscal periods. This will cause a reduction of earnings in the near future. If informed traders want to reduce investment risk as sophisticated investors, they may react differentially to increases in inventory according to the level of information asymmetry in each firm.

\footnotetext{
${ }^{4}$ Dropping either For_Buyv or Inst_Buyv in models (4) and (5) does not change our conclusion and yields qualitatively identical results.

${ }^{5}$ To mitigate the heteroscedasticity problem, heteroscedasticity-consistent estimators are used as in White (1980). The Durbin-Watson test does not provide statistical evidence of autocorrelation in our regression models (not tabulated).
} 
Consistent with this conjecture, institutional investors also reduce net amounts (Inst_Netv), buying (Inst_Buyv), and selling amounts (Inst_Sellv) when firms with information asymmetry increase the level of inventory. As for buying patterns, institutional traders increase buying amounts in proportion to increased inventory in firms with low information asymmetry, but buying amounts are reduced more in firms with high information asymmetry. The coefficient of $C P A I^{*} I A$ in the Inst_Buyv model is negative, and the absolute value of this coefficient is greater than the positive coefficient of $C P A I$. This result indicates that the more firms with information asymmetry expand their current inventory, the more institutional traders reduce buying amounts compared to the previous period.

When we include the previous change in inventory $(p C P A I)$, there are insignificant additional effects on trading patterns of institutional investors. This result indicates that institutional traders are likely to reflect timely information about current changes in inventory rather than previous changes.

The coefficients for several control variables are significant. The variable of $B M$ is negatively associated with institutional trading patterns, since investors prefer growing firms which record low values of $B M$. Consistent with the results for $B M$, the variable of RET and STD are positively related to the trading patterns of informed traders (Chae, 2005; Watanabe, 2008).

Table 4: Informed Traders and Inventory Changes in Firms with Information Asymmetry - Institutional Traders

\begin{tabular}{|c|c|c|c|c|c|c|c|c|}
\hline \multirow[b]{2}{*}{ Variables } & \multicolumn{2}{|c|}{ Inst_Absv } & \multicolumn{2}{|c|}{ Inst_Netv } & \multicolumn{2}{|c|}{ Inst_Buyv } & \multicolumn{2}{|c|}{ Inst_Sellv } \\
\hline & Coeff. & $\begin{array}{l}\text { White t } \\
\text { value }\end{array}$ & Coeff. & $\begin{array}{l}\text { White t } \\
\text { value }\end{array}$ & Coeff. & $\begin{array}{l}\text { White t } \\
\text { value }\end{array}$ & Coeff. & $\begin{array}{c}\text { White t } \\
\text { value }\end{array}$ \\
\hline Intercept & -0.4623 & $-2.80^{* * *}$ & 0.0467 & 0.50 & -0.2447 & $-2.19^{* *}$ & -0.3754 & -3.51 *** \\
\hline$I A$ & -0.0106 & -0.54 & 0.0016 & 0.14 & -0.0012 & -0.09 & -0.0033 & -0.26 \\
\hline pCPAI & 0.1165 & 1.25 & -0.0322 & -0.81 & 0.0674 & 1.15 & 0.0855 & 1.46 \\
\hline$p C P A I * I A$ & -0.2385 & -1.12 & -0.0134 & -0.16 & -0.1335 & -1.00 & -0.1663 & -1.28 \\
\hline CPAI & 0.0578 & 1.27 & 0.0359 & 1.43 & 0.0557 & $1.90^{*}$ & 0.0166 & 0.56 \\
\hline$C P A I * I A$ & -0.3667 & $-3.73^{* * *}$ & -0.0853 & $-1.99^{* *}$ & -0.2601 & $-4.11^{* * * *}$ & -0.1709 & $-2.71^{* * * *}$ \\
\hline SIZE & 0.0168 & $2.77^{* * * *}$ & -0.0025 & -0.75 & 0.0084 & $2.06^{* *}$ & 0.0144 & $3.67^{* * * *}$ \\
\hline$B M$ & -0.0117 & -1.32 & 0.0045 & 0.85 & -0.0047 & -0.76 & -0.0127 & $-2.22^{* *}$ \\
\hline$R E T$ & 6.1278 & $10.36^{* * * *}$ & 0.5503 & $1.84^{*}$ & 4.0294 & $10.21^{* * * *}$ & 3.3769 & $8.89^{* * *}$ \\
\hline$S T D$ & 0.7310 & $2.58^{* * *}$ & 0.3164 & $1.90^{*}$ & 0.3985 & $2.18^{* * *}$ & 0.3048 & 1.59 \\
\hline For_Buyv & 0.6171 & $9.04^{* * * *}$ & -0.1436 & $-3.54^{* * *}$ & 0.3387 & $7.40^{* * * *}$ & 0.4392 & $9.70^{* * * *}$ \\
\hline$I N D / Y E A R$ & Included & & Included & & Included & & Included & \\
\hline F-value & $44.78^{* * * *}$ & & $2.33^{* * *}$ & & $36.79^{* * *}$ & & $42.50^{* * * *}$ & \\
\hline Adj R square & 0.3157 & & 0.0139 & & 0.2739 & & 0.3043 & \\
\hline Max VIF & 0.26 & & 0.87 & & 0.45 & & 0.58 & \\
\hline$\underline{\mathbf{N}}$ & 1,709 & & 1,709 & & 1,709 & & 1,709 & \\
\hline
\end{tabular}

In Table 5, we provide the results for the trading patterns of foreign traders using the change in the percent of production added to inventory for the current and previous inventory (CPAI and $p C P A I)$. The For_Absv model represents the association between $C P A I$ and $p C P A I$ and absolute total trading amounts by foreigners. Using the For_Sellv model, we examine how the change in inventory is related to foreign investors' behavior. In both the For_Absv and For_Sellv models, the coefficient of CPAI is negative and significant. This indicates that foreign traders tend to reduce selling amounts according to current increases in inventory, but that buying amounts are not associated with CPAI. Consistent with Brennan and Cao (1997), this result shows that foreign investors have a tendency to avoid investment risk and to behave more conservatively when they are at an information disadvantage than domestic traders.

The relation between the previous change in the percent of inventory ( $p C P A I)$ and the change in trading amounts of foreigners is insignificant. From this result, we can infer that foreign traders tend to reflect timely changes in inventory rather than previous changes. However, we fail to find additional effects of information asymmetry on the trading patterns of foreign investors. 
Regarding control variables, $B M$ is negatively associated with foreign trading patterns, which demonstrates that firms with high growth options due to low $B M$ attract foreign investors that prefer growing firms. In accordance with the results for $B M$, the variables for RET and $S T D$ are positively related to the trading patterns of informed traders (Chae, 2005; Watanabe, 2008).

Table 5: Informed Traders and Inventory Changes in Firms with Information Asymmetry - Foreign Traders

\begin{tabular}{|c|c|c|c|c|c|c|c|c|}
\hline \multirow[b]{2}{*}{ Variables } & \multicolumn{2}{|c|}{ For_Absv } & \multicolumn{2}{|c|}{ For_Netv } & \multicolumn{2}{|c|}{ For_Buyv } & \multicolumn{2}{|c|}{ For_Sellv } \\
\hline & Coeff. & $\begin{array}{l}\text { White } \mathrm{t} \\
\text { value }\end{array}$ & Coeff. & $\begin{array}{l}\text { White } t \\
\text { value }\end{array}$ & Coeff. & $\begin{array}{l}\text { White } \mathrm{t} \\
\text { value }\end{array}$ & Coeff. & $\begin{array}{l}\text { White } \mathrm{t} \\
\text { value }\end{array}$ \\
\hline Intercept & 0.0447 & 0.31 & -0.2257 & $-3.27^{* * *}$ & -0.0236 & -0.27 & 0.1353 & 1.46 \\
\hline$I A$ & 0.0104 & 0.68 & -0.0072 & -0.90 & 0.0073 & 0.77 & 0.0100 & 1.01 \\
\hline pCPAI & -0.0809 & -1.31 & 0.0027 & 0.12 & -0.0535 & -1.37 & -0.0485 & -1.29 \\
\hline$p C P A I * I A$ & 0.0196 & 0.20 & 0.0584 & 0.94 & 0.0564 & 0.81 & -0.0244 & -0.45 \\
\hline CPAI & -0.0865 & $-2.06^{* *}$ & 0.0285 & $2.12^{* *}$ & -0.0372 & -1.52 & -0.0642 & $-2.43^{* *}$ \\
\hline CPAI*IA & 0.0353 & 0.45 & -0.0386 & -1.34 & -0.0019 & -0.04 & 0.0557 & 1.12 \\
\hline SIZE & 0.0020 & 0.38 & 0.0089 & $3.50^{* * *}$ & 0.0032 & 1.02 & -0.0032 & -0.97 \\
\hline$B M$ & -0.0411 & $-5.73^{* * *}$ & -0.0044 & -1.19 & -0.0252 & $-5.73^{* * * *}$ & -0.0228 & $-4.82^{* * * *}$ \\
\hline RET & 6.1260 & $12.33^{* * * *}$ & 0.9346 & $4.08^{* * *}$ & 4.0179 & $13.22^{* * * *}$ & 3.1575 & $9.34^{* * *}$ \\
\hline$S T D$ & 2.8883 & $11.01^{* * *}$ & -0.0160 & -0.14 & 1.7166 & $10.50^{* * * *}$ & 1.6596 & $9.70^{* * * *}$ \\
\hline Inst_Buyv & 0.3821 & $10.72^{* * *}$ & -0.0746 & $-2.95^{* * *}$ & 0.1727 & $7.64^{* * *}$ & 0.2697 & $10.73^{* * *}$ \\
\hline IND/YEAR & Included & & Included & & Included & & Included & \\
\hline F-value & $87.63^{\text {*** }}$ & & $3.11^{* * * *}$ & & $74.76^{* *}$ & & $70.94^{* * * *}$ & \\
\hline Adj R square & 0.4773 & & 0.0217 & & 0.4374 & & 0.4243 & \\
\hline Max VIF & 0.84 & & 0.90 & & 0.97 & & 0.65 & \\
\hline $\mathbf{N}$ & 1,709 & & 1,709 & & 1,709 & & 1,709 & \\
\hline
\end{tabular}

\section{Regression Results: Abnormal Inventory}

Table 6 includes the results of testing of the third and fourth hypotheses about institutional traders and abnormal inventory. In this model, we use abnormal changes in the current and the previous inventory (Abn_Inv and $\left.p A b n \_I n v\right)$. Roychowdhury (2006) suggests a modified model for detecting abnormal increases or decreases in inventory. Using this model, we can statistically determine the abnormal status of inventory in each firm. If a firm has increased inventory in terms of $C P A I$ and $p C P A I$, a trend toward increasing customer orders and inflation of raw materials may be included in increased $C P A I$ and $p C P A I$ during specific periods. When we use abnormal values for the change in inventory, we can exclude other factors affecting the trend in inventory changes.

After controlling for these trend-related factors, we find that buying amounts by institutional traders (Inst_Buyv) are negatively related to increases in $A b n_{-} I n v$ in firms with information asymmetry. This result also shows that these factors $\left(A b n_{-} I n v^{*} I A\right)$ influence the total amounts of buying and selling by institutional traders (Inst_Absv).

Consistent with the results for $C P A I$, institutional traders are likely to respond to information about current abnormal changes in inventory (Abn_Inv), especially when making their buying decisions. 
Table 6: Informed Traders and Inventory Changes in Firms with Information Asymmetry - Institutional Traders

\begin{tabular}{|c|c|c|c|c|c|c|c|c|}
\hline \multirow[b]{2}{*}{ Variables } & \multicolumn{2}{|c|}{ Inst_Absv } & \multicolumn{2}{|c|}{ Inst_Netv } & \multicolumn{2}{|c|}{ Inst_Buyv } & \multicolumn{2}{|c|}{ Inst_Sellv } \\
\hline & Coeff. & $\begin{array}{l}\text { White t } \\
\text { value }\end{array}$ & Coeff. & $\begin{array}{l}\text { White t } \\
\text { value }\end{array}$ & Coeff. & $\begin{array}{l}\text { White } t \\
\text { value }\end{array}$ & Coeff. & $\begin{array}{l}\text { White t } \\
\text { value }\end{array}$ \\
\hline Intercept & -0.4496 & $-2.71^{* * *}$ & 0.0542 & 0.58 & -0.2361 & $-2.10^{* *}$ & -0.3672 & $-3.42^{* * * *}$ \\
\hline$I A$ & -0.0117 & -0.60 & 0.0018 & 0.16 & -0.0017 & -0.13 & -0.0044 & -0.35 \\
\hline$p A b n \_I n v$ & 0.0033 & 0.35 & 0.0005 & 0.09 & 0.0013 & 0.22 & 0.0037 & 0.60 \\
\hline$p A b n \_I n v * I A$ & 0.0094 & 0.45 & -0.0060 & -0.53 & 0.0078 & 0.57 & 0.0017 & 0.13 \\
\hline$A b n \_\bar{I} n v$ & 0.0165 & $1.66^{*}$ & 0.0017 & 0.31 & 0.0110 & 1.60 & 0.0085 & 1.38 \\
\hline$A b n \_I n v * I A$ & -0.0458 & $-2.20^{* * *}$ & -0.0127 & -1.07 & -0.0317 & $-2.40^{* *}$ & -0.0221 & -1.64 \\
\hline$S I Z E$ & 0.0164 & $2.69^{* * * *}$ & -0.0029 & -0.85 & 0.0082 & $1.98^{* *}$ & 0.0142 & $3.61^{\text {*** }}$ \\
\hline$B M$ & -0.0103 & -1.16 & 0.0044 & 0.84 & -0.0037 & -0.60 & -0.0120 & $-2.11^{* * *}$ \\
\hline RET & 6.0276 & $10.18^{* * *}$ & 0.5405 & $1.82^{*}$ & 3.9623 & $10.05^{* * *}$ & 3.3253 & $8.76^{* * *}$ \\
\hline$S T D$ & 0.7007 & $2.47^{* *}$ & 0.2978 & $1.77^{*}$ & 0.3746 & $2.04^{* *}$ & 0.2918 & 1.52 \\
\hline For_Buyv & 0.6215 & $9.05^{* * *}$ & -0.1436 & $-3.55^{* * *}$ & 0.3412 & $7.41^{* * * *}$ & 0.4418 & $9.70^{* * * *}$ \\
\hline IND/YEAR & Included & & Included & & Included & & Included & \\
\hline F-value & $44.3^{* * *}$ & & $2.21^{* * * *}$ & & $36.32^{* * *}$ & & $42.15^{* * *}$ & \\
\hline Adj R square & 0.3134 & & 0.0126 & & 0.2713 & & 0.3025 & \\
\hline Max VIF & 0.73 & & 0.93 & & 0.83 & & 0.90 & \\
\hline$\underline{\mathbf{N}}$ & 1,709 & & 1,709 & & 1,709 & & 1,709 & \\
\hline
\end{tabular}

The For_Absv model in Table 7 shows that foreign traders tend to increase net trading amounts when abnormal inventory (Abn_Inv) is higher, as in Table 5 with CPAI. However, insignificant relations are found between trading patterns of foreign investors and abnormal changes in inventory in firms with information asymmetry. Moreover, buying patterns are only related to previous abnormal inventory, not current abnormal inventory.

In summary, we predict that trading patterns of informed traders are likely to reflect informative changes in inventory. We find that institutional traders consider timely information about current changes in inventory rather than previous changes. Institutional investors tend to reduce buying and selling amounts when firms with information asymmetry expand their current inventory. This tendency is also evident in the model including abnormal inventory. In detail, institutional traders reduce buying amounts when abnormal inventory is high in firms with information asymmetry. However, trading amounts by foreign traders are only associated with current changes in inventory, and the effect of information asymmetry is insignificant. When we include abnormal inventory in the regression model, buying amounts by foreign investors are negatively related to previous abnormal inventory, and the effect of information asymmetry is insignificant, as in the regression model including CPAI. As in Brennan and Cao (1997), increased inventory could be bad news to foreigners regardless of information asymmetry because foreign investors may be at an information disadvantage and therefore avoid investment risk more than domestic traders. This result suggests that changes in inventory are informative for informed traders. This phenomenon is more clearly observed in the behavior of institutional traders when firms experience information asymmetry, which measured by the high ratio of bid-ask spreads. 
Table 7: Informed Traders and Inventory Changes in Firms with Information Asymmetry - Foreign Traders

\begin{tabular}{|c|c|c|c|c|c|c|c|c|}
\hline \multirow[b]{2}{*}{ Variables } & \multicolumn{2}{|c|}{ For_Absv } & \multicolumn{2}{|c|}{ For_Netv } & \multicolumn{2}{|c|}{ For_Buyv } & \multicolumn{2}{|c|}{ For_Sellv } \\
\hline & Coeff. & $\begin{array}{l}\text { White t } \\
\text { value }\end{array}$ & Coeff. & $\begin{array}{l}\text { White t } \\
\text { value }\end{array}$ & Coeff. & $\begin{array}{l}\text { White t } \\
\text { value }\end{array}$ & Coeff. & $\begin{array}{c}\text { White t } \\
\text { value }\end{array}$ \\
\hline Intercept & 0.0314 & 0.22 & -0.2236 & $-3.24^{* * * *}$ & -0.0329 & -0.37 & 0.1290 & 1.40 \\
\hline$I A$ & 0.0109 & 0.72 & -0.0062 & -0.79 & 0.0082 & 0.88 & 0.0097 & 0.99 \\
\hline$p A b n \_I n v$ & -0.0098 & -1.30 & -0.0029 & -0.72 & -0.0084 & $-1.79^{*}$ & -0.0032 & -0.66 \\
\hline$p A b n \_I n v^{*} I A$ & -0.0078 & -0.45 & -0.0062 & -0.71 & -0.0045 & -0.41 & -0.0060 & -0.56 \\
\hline$A b n \_I n v$ & -0.0047 & -0.59 & 0.0073 & $1.72^{*}$ & -0.0004 & -0.07 & -0.0061 & -1.25 \\
\hline$A b n \_I n v * I A$ & 0.0012 & 0.08 & -0.0067 & -0.79 & -0.0007 & -0.07 & 0.0039 & 0.39 \\
\hline$S I Z \bar{E}$ & 0.0024 & 0.46 & 0.0088 & $3.47^{* * *}$ & 0.0035 & 1.11 & -0.0031 & -0.92 \\
\hline$B M$ & -0.0407 & $-5.69^{* * * *}$ & -0.0041 & -1.12 & -0.0247 & $-5.68^{* * * *}$ & -0.0228 & $-4.83^{* * * *}$ \\
\hline$R E T$ & 6.1284 & $12.36^{* * *}$ & 0.9257 & $4.07^{* * *}$ & 4.0125 & $13.25^{* * *}$ & 3.1698 & $9.41^{* * *}$ \\
\hline$S T D$ & 2.9129 & $11.14^{* * * *}$ & -0.0285 & -0.25 & 1.7275 & $10.61^{* * * *}$ & 1.6775 & $9.82^{* * * *}$ \\
\hline Inst_Buyv & 0.3824 & $10.70^{* * * *}$ & -0.0745 & $-2.96^{* * *}$ & 0.1732 & $7.68^{* * * *}$ & 0.2695 & $10.69^{* * *}$ \\
\hline$I N D / Y E A R$ & Included & & Included & & Included & & Included & \\
\hline F-value & $87.43^{\text {**** }}$ & & $3.27^{* * * *}$ & & $74.96^{* * *}$ & & $70.55^{* * *}$ & \\
\hline Adj R square & 0.4767 & & 0.0233 & & 0.438 & & 0.423 & \\
\hline Max VIF & 0.94 & & 0.80 & & 0.94 & & 0.69 & \\
\hline$\underline{\mathbf{N}}$ & 1,709 & & 1,709 & & 1,709 & & 1,709 & \\
\hline
\end{tabular}

\section{CONCLUSION}

In this study, we examine how changes in inventory are associated with the trading patterns of foreign and institutional investors. To test how these changes are related to the activities of informed traders, we utilize changes in the amount of informed trading. We also include the information environment in our regression analyses. Firms with different levels of information asymmetry, which is treated as a proxy for investment risk associated with stock trading, are examined in the analyses. After controlling for firm-specific factors, we show evidence that changes in inventory are associated with changes in the amount of foreign and institutional trading. Furthermore, we demonstrate an enhanced relation between institutional trading activities and changes in inventory when firms experience high levels of information asymmetry, as measured by the ratio of bid-ask spreads. This result indicates that inventory changes can be informative for informed traders. Informed traders tend to respond to changes in inventory and to reflect this information according to the level of information asymmetry in each firm. Moreover, we find that informed traders consider abnormal inventory during the current or previous periods, and that foreign traders show more conservative trading patterns than domestic institutional investors. From the results of this study, stakeholders in the capital market may improve their understanding of the relation between informed trading patterns and inventory changes in firms with information asymmetry.

This study adds to the existing informed trading and inventory literature by providing additional evidence of the relation between changes in inventory and informed trading in firms with investment risk. This study may also help capital market participants to improve their understanding of the informativeness of inventory in such firms. Future research may focus on the effects of various characteristics of investment risk and other types of informed trading activities in firms with different operations strategies. 
Table 8: Definitions of Variables

Inst_Absv = the natural log of changes in absolute total trading amounts by institutional traders scaled by market value between year $\mathrm{t}$ and year $\mathrm{t}-1$;

Inst_Netv = the natural log of changes in net buying amounts by institutional traders scaled by market value between year $\mathrm{t}$ and year $\mathrm{t}-1$;

Inst_Buyv = the natural log of changes in stock purchase amounts by institutional traders scaled by market value between year $\mathrm{t}$ and year $\mathrm{t}-1$;

Inst_Sellv = the natural log of changes in stock selling amounts by institutional traders scaled by market value between year $\mathrm{t}$ and year $\mathrm{t}-1$;

For_Absv = the natural log of changes in absolute total trading amounts by foreign traders scaled by market value between year $\mathrm{t}$ and year $\mathrm{t}-1$;

For_Netv $=$ the natural log of changes in net buying amounts by foreign traders scaled by market value between year $\mathrm{t}$ and year $\mathrm{t}-1$

For_Buyv $=$ the natural log of changes in stock purchase amounts by foreign traders scaled by market value between year $t$ and year $\mathrm{t}-1$

For_Sellv $=$ the natural log of changes in stock selling amounts by foreign traders scaled by market value between year $\mathrm{t}$ and year $\mathrm{t}-1$;

$I A=1$ if a firm has a high level of information asymmetry, and 0 otherwise;

$p C P A I=$ the previous value of an estimate of the change in the percent of production added to inventory;

$p A b n \_I n v=$ instead of $p C P A I$, the previous value of the abnormal inventory from equation (3), for testing the third and fourth hypotheses;

$C P A I=$ the current estimate of the change in the percent of production added to inventory;

$A b n \_I n v=$ instead of CPAI, the current value of abnormal inventory from equation (3) for testing the third and fourth hypotheses;

$S I Z E=$ the natural $\log$ of total assets at the beginning;

$B M=$ the ratio of equity scaled by market value at the beginning;

$R E T=$ the accumulated value of daily stock returns during a given period;

$S T D=$ the yearly change in stock volatility from daily low and high prices scaled by the mean value of stock prices; and

$I N D \& Y E A R=$ dummies representing each industry and year.

\section{AUTHORS INFORMATION}

Gyungmin Pyo, Ph.D., Assistant Professor, Konyang University, College of Global Business Administration, 121 Daehak-ro, Nonsan, Chungman 320-711, South Korea.

E-mail: gyung@konyang.ac.kr

Yerim Chung, Ph.D., Assistant Professor, Yonsei University, School of Business, 50 Yonsei-ro, Seodaemun-gu, Seoul 120-749, South Korea. +82 22123 2504. E-mail: yerimchung@yonsei.ac.kr (Corresponding author)

\section{REFERENCES}

Baiman, S., Netessine, S., and Saouma, R. (2010) Informativeness, Incentive Compensation, and the Choice of Inventory Buffer, The accounting Review 85(6), 1839-1860.

Brennan, M.J. and Cao, H. H. (1997) International Portfolio Investment Flows, The Journal of Finance, 52(5), 18511880.

Chae, J. (2005) Trading Volume, Information Asymmetry, and Timing Information, The Journal of Finance 60(1), 413-442.

Choe, H., Kho, B.-C., and Stulz, R. M. (2005) Do Domestic Investors Have an Edge? The Trading Experience of Foreign Investors in Korea, The Review of Financial Studies 18(3), 795-829.

Cohen, L., Malloy, C., and Pomorski, L. (2012) Decoding Inside Information, The Journal of Finance, 67(3), 10091043.

Copeland and Galai (1983) Information effects on the bid-ask spread, The Journal of Finance 38(5), 1457-1469.

Easley, D. and O'Hara, M. (2004) Information and the Cost of Capital, The Journal of Finance 59(4), 1553-1583.

Grinblatt, M. and Keloharju, M. (2000) The Investment Behavior and Performance of Various Investor Types: a Study of Finland's Unique Data Set, Journal of Financial Economics, 55(1), 43-67.

Gu, F. and Li, J. Q. (2007) The Credibility of Voluntary Disclosure and Insider Stock Transactions, Journal of Accounting Research, 45(4), 771-810. 
Jiambalvo, J., Noreen, E., and Shevlin, T. (1997) Incremental Information Content of the Change in the Percent of Production Added to Inventory, Contemporary Accounting Research 14(1), 69-97.

Roychowdhury, S. (2006) Earnings management through real activities manipulation, Journal of Accounting and Economics 42, 335-370.

Smith, C. W. Jr and Watts, R. L. (1992) The Investment Opportunity Set and Corporate Financing, Dividend, and Compensation Policies, Journal of Financial Economics, 32(3), 263-292.

Sun, Y. (2010) Do MD\&A Disclosures Help Users Interpret Disproportionate Inventory Increases?, The accounting Review 85(4),1411-1440.

Thomas, J. K. and Zhang, H. (2010) Inventory Changes and Future Returns, Review of Accounting Studies 7, 163187.

Watanabe, M. (2008) Price Volatility and Investor Behavior in an Overlapping Generations Model with Information Asymmetry, The Journal of Finance 53(1), 229-272.

White, H. (1980) A Heteroskedasticity-Consistent Covariance Matrix Estimator and a Direct Test for Heteroskedasticity, Econometrica, 48(4), 817-838. 